\title{
Long-term persistence of sedimentary copper contamination in Lake Orta: potential environmental risks 20 years after liming
}

\author{
Davide A.L. VIGNATI ${ }^{1 *}{ }^{*}$ Roberta BETTINETTI, ${ }^{2}$ Aldo MARCHETTO ${ }^{3}$ \\ ${ }^{1}$ National Research Council, Water Research Institute, UOS Brugherio, Via del Mulino 19, 20861 Brugherio (MB); ${ }^{2}$ Department of Theoretical \\ and Applied Sciences, Insubria University, Via Valleggio 11, 22100 Como; ${ }^{3}$ National Research Council, Institute of Ecosystem Study, \\ L. Tonolli 50, 28922 Verbania- Pallanza, Italy. \\ *Corresponding author: david-anselmo.vignati@univ-lorraine.fr \\ ${ }^{\S}$ Current address: CNRS and Université de Lorraine, Laboratoire Interdisciplinaire des Environnements Continentaux UMR7360, \\ Metz, F-57070, France.
}

\begin{abstract}
Lake Orta, northern Italy, has suffered from severe copper pollution and human-induced acidification between the 1920s and the 1990s because of discharges from a rayon factory and electroplating industries located in its drainage basin. Following liming operations in the late 1980s, the chemical quality of the water column has been restored and signs of, still ongoing, biological recovery observed. Two sediment cores $(07 / 1 \mathrm{~A}$ and $07 / 1 \mathrm{~B})$ were collected close to the main historical Cu discharge (in the southern part of the lake) and one (07/2A) in the central part of the lake. Cores 07/1A and 07/2A were analyzed for Cu content, Loss on Ignition (LOI) and water content. Diatom profiles (cores 07/1B and 07/2A) were used to confirm sediment dating and to identify alterations in the sediment sequence because, among other taxonomic groups, diatom assemblages were strongly affected by lake pollution and recovery. Copper concentrations in the uppermost layers of sediment cores (2007 AD) were above 1,000 $\mathrm{mg} \mathrm{kg}^{-1}$ and around $500 \mathrm{mg} \mathrm{kg}^{-1}$ in cores 07/1 A and 07/2 A, respectively. These values were lower than the corresponding maximum ones of approx. 3500 and $4500 \mathrm{mg} \mathrm{kg}^{-1}$ recorded at the end of the 1950s at both locations, but remained 10 to 40-fold higher than the pre-industrial levels of about $40 \mathrm{mg} \mathrm{kg}^{-1}$ measured in both cores. Diatom profiles revealed a continuous sedimentation pattern in core 07/1A, but highlighted interruptions in sediment deposition in core 07/2A. Copper levels in 2007 were still comparable to or higher than concentrations reported to cause adverse effect on the survival, growth and reproduction of sediment-ingesting organisms. A critical comparison of measured concentrations with relevant ecotoxicological values suggests that particular attention should be given to understand the effects of dietary ingestion of sedimentary $\mathrm{Cu}$ which, unlike in previous ecotoxicological studies, may now represent the main route of exposure to $\mathrm{Cu}$ for sediment-ingesting benthic organisms.
\end{abstract}

Key words: Lake Orta; copper contamination; fossil diatoms; paleoecotoxicology; legacy pollution.

Received: April 2015. Accepted: October 2015.

\section{INTRODUCTION}

Lake bottom sediments are faithful temporal archives of events and processes that occur in the overlying water column and in the drainage basin. In particular, sediments can show the footprints of past chemical discharges long after the corresponding inputs to the overlying water column have been stopped or reduced to environmentally acceptable levels (Guilizzoni et al., 2012). Because many organisms live in or are in contact with the bottom, sediment may act as an important route of exposure to aquatic organisms. Copper is an essential trace element whose geochemical cycle has been severely disrupted by human uses since Roman times (Hong et al., 1996) and, even nowadays, often occurs in sediments at levels high enough to alter organisms' health or ecosystem functioning (Gardham et al., 2015).

In Italy, a dramatic case of copper contamination has been well documented starting from the early $20^{\text {th }}$ century (Bonacina and Baudo, 2001). Lake Orta, a deep southern
Alpine lake, has been heavily polluted by copper and ammonium sulfates through a direct input from an industrial rayon factory manufacturing since 1926 . The increase in the concentrations of heavy metals led to a rapid disappearance of many water life forms, and dramatic change in the species composition of planktonic communities including e.g., cladocerans (Manca and Comoli, 1995) and diatom assemblages (Ruggiu et al., 1998). A treatment plant for copper recovery was adopted by the factory in 1958. However, this improvement was counterbalanced by a number of electrogalvanic activities that, over the same period, developed in the lake's watershed with direct discharges into its basin. Moreover, lake water had a low natural buffering capacity due to the watershed geology: mainly gneiss, micaschists and granites. As a consequence, starting from the 1960s, the biochemical oxidation of ammonium acidified the lake water down to the lowest $\mathrm{pH}$ value of 3.8 units that was reached in 1985 . To recover the lake from acidification, a liming intervention was carried out in 1989/90 by spreading a suspension of finely pow- 
dered natural limestone on the water surface. Post-liming investigations showed a recovery of the main chemical characteristics of the water column (mainly $\mathrm{pH}$ and ammonium) associated with a slower restoration of the trophic web. Nonetheless, the vulnerability and the instability of the lake were pointed out by the last survey including chemical and biological information carried out in 2001 (Bonacina, 2001). For example, nowadays the zooplankton community is more structured and diversified than in the past, but it seems that still remains substantially different from the original one (Piscia et al., 2016).

The bottom environment was also strongly affected by the anthropogenic discharges and sediments quickly became highly enriched in copper after the opening of the rayon factory. Despite several interventions to reduce $\mathrm{Cu}$ releases from the rayon factory (Corbella et al., 1958), other authors have documented the persistence of sediment contamination in the 1980s (Provini et al., 1987) and in the late 1990s (Baudo and Beltrami, 2001). Ecotoxicological studies confirmed the adverse effect of sediment contamination on various target organisms including invertebrates, plants, and bacteria (Guzzella et al., 1996; Rossi and Beltrami, 1998; Burton et al., 2001). Yet, all ecotoxicological evaluations focused on risk to pelagic or epibenthic organisms without considering possible effects to sediment-ingesting organisms such as chironomids, oligochaetes or tubificids. Using spiked artificial sediments, Roman et al. (2007) showed that copper concentrations causing a $50 \%$ reduction in survival or growth of Chironomus riparius, Lumbriculus variegatus and Tubifex tubifex ranged between 211 and $327 \mathrm{mg} \mathrm{kg}^{-1}$ dry weight (d.w.) for survival and 126 and $150 \mathrm{mg} \mathrm{kg}^{-1}$ d.w. for growth. Pasteris et al. (2003) determined values between 81 and $107 \mathrm{mg} \mathrm{kg}^{-1}$ d.w. for the number of youngs produced by individuals of $T$. tubifex exposed for 28 days to a $\mathrm{Cu}$-spiked reconstructed sediments. In the case of spiked natural sediments, Méndez-Fernández et al. (2013) reported similar results for growth and survival of T. tubifex, while Cairns et al. (1984) observed effects on the survival of $C$. tentans only at concentrations between 685 and 3100 $\mathrm{mg} \mathrm{kg}{ }^{-1}$. Copper concentrations measured in Lake Orta sediments (see Baudo and Beltrami, 2001 for a review) are often in the range reported to be potentially toxic to sediment-dwelling organisms; also when compared with toxic concentrations in spiked natural sediments. Although the actual $\mathrm{Cu}$ toxicity will depend on sediments characteristics (Simpson, 2005; Campana et al., 2013), a comparison of the recent state of $\mathrm{Cu}$ contamination in Lake Orta with available information on potentially toxic sediment concentrations would be instructive.

Here, we present a detailed chronology of $\mathrm{Cu}$ contamination and diatom profiles from the pre-industrial period until 2007 at 2 sites of Lake Orta located at a different distance from known pollution sources. Diatom profiles, compared with the known history of lake phytoplankton and with a previous study (Ruggiu et al., 1998), were used to confirm sediment dating and to identify the presence of irregularities in sediment deposition. Specifically, the present work will examine if sediment contamination decreased over the decade 1997-2007, if liming has left a clear mark on $\mathrm{Cu}$ sediment concentrations and if $\mathrm{Cu}$ concentrations are similar in the southern and central part of the basin. Furthermore, data on the most recent levels of $\mathrm{Cu}$ in bed sediments will be assessed for the potential of residual $\mathrm{Cu}$ contamination to cause toxicity to sedimentdwelling organism.

\section{METHODS}

Three sediment cores were collected in October 2007 with a gravity corer (inner diameter $6.3 \mathrm{~cm}$ ) in Lake Orta. Cores $07 / 1 \mathrm{~A}(52.5 \mathrm{~cm}$ in length) and its parallel core $07 / 1 \mathrm{~B}$ $(46.5 \mathrm{~cm})$ were sampled in the southern basin of the lake at a depth of $31 \mathrm{~m}$ in an undisturbed area $\left(45^{\circ} 46^{\prime} 35^{\prime \prime} \mathrm{N}, 8^{\circ}\right.$ $24^{\prime} 56^{\prime \prime}$ E) not far from the rayon factory (Fig. 1). Core $07 / 2 \mathrm{~A}(61.5 \mathrm{~cm})$ was collected in the deepest part $(>100 \mathrm{~m})$ of the central part of the basin $\left(45^{\circ} 48^{\prime} 44^{\prime \prime} \mathrm{N}, 8^{\circ} 23^{\prime} 35^{\prime \prime} \mathrm{E}\right.$;

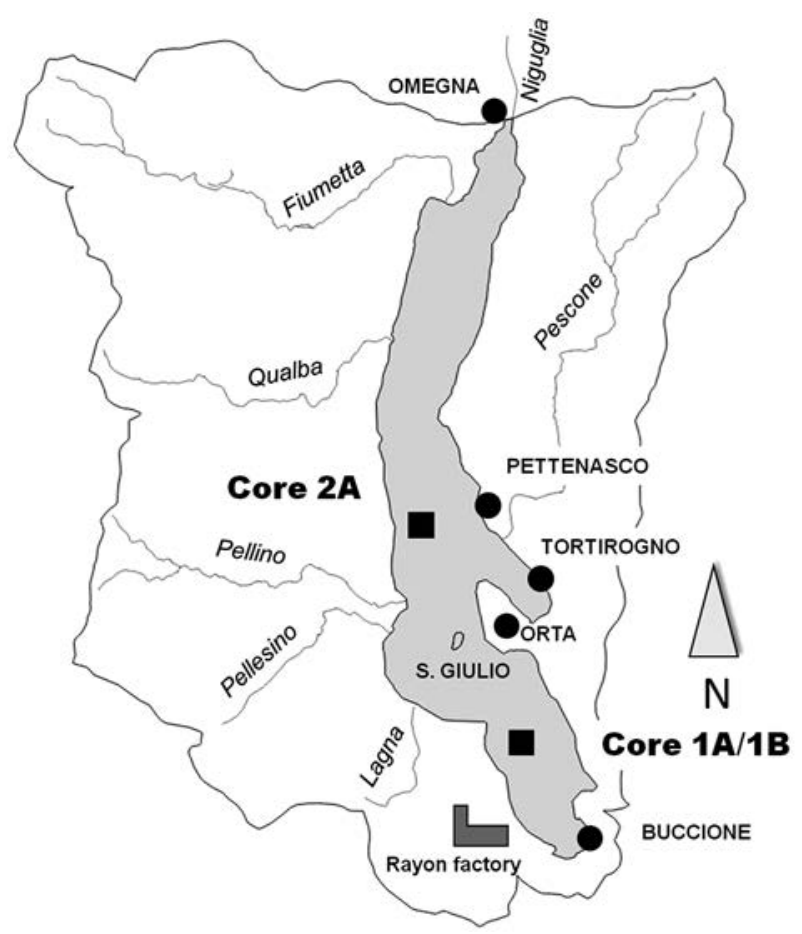

Fig. 1. Map of Lake Orta with indication of the sampling points (black squares) for this study and of the position of the rayon factory at the south end of the lake. Major towns of interest (Omegna, Pettenasco, Orta, Tortirogno, and Buccione) are also shown as black circles. Among tributaries, note the position of river Lagna whose basin is characterized by the presence of metal-releasing activites (i.e. electroplating industries). 
Fig. 1). All cores were stored in the dark at $4^{\circ} \mathrm{C}$. Once opened longitudinally, cores were visually inspected and, because they comprised mainly clastic and homogeneous materials, they were subsampled into $1 \mathrm{~cm}$ slices. Radiometric dating was performed on cores $07 / 1 \mathrm{~A}$ and $07 / 2 \mathrm{~A}$ by P. Appleby, Liverpool University, Environmental Radioactivity Laboratory, through the analyses of ${ }^{210} \mathrm{~Pb}$ and ${ }^{137} \mathrm{Cs}$ radionuclides by direct gamma assay using Ortec HPGe GWL series well-type coaxial low-background intrinsic germanium detectors (Appleby et al., 1986; Piscia et al., 2012). Core 07/1B was only used for diatom analysis and was dated after core-to-core stratigraphic correlation. An evident change in sediment color at the depth of $5.5 \mathrm{~cm}$ was correlated with a very similar change in core $07 / 1 \mathrm{~A}$ at the depth of $4 \mathrm{~cm}$.

In core $07 / 1 \mathrm{~A}$, total $\mathrm{Cu}$ content was measured every $\mathrm{cm}$ in the first upper $6 \mathrm{~cm}$ and then at 10,20,40, and 51.5 $\mathrm{cm}$. In core $07 / 2 \mathrm{~A}$, total $\mathrm{Cu}$ content was measured in all sections of the uppermost $20 \mathrm{~cm}$, every $5 \mathrm{~cm}$ from 25 to $50 \mathrm{~cm}$ and at $60.5 \mathrm{~cm}$ corresponding to the core bottom. About $50 \mathrm{mg}$ dry mass of each section were weighed into Teflon bombs and mineralized by microwave assisted digestion (Milestone, MLS 1200) with $3 \mathrm{~mL}$ of concentrated nitric acid $(65 \% \mathrm{v} / \mathrm{v}$, VWR, Suprapur) and $1 \mathrm{~mL}$ of ultrapure water (milliQ, Bernstein, Nanopure). Procedural blanks and reference material S7 from the AQUACON project CHECK (certified $\mathrm{Cu}$ content $100 \pm 2 \mathrm{mg} \mathrm{kg}^{-1}$ ) were included in each digestion run. After each digestion, Teflon bombs were cleaned three times with $50 \% \mathrm{v} / \mathrm{v}$ analytical grade nitric acid while heating in the microwave oven for 5 minutes at $500 \mathrm{~W}$.

The digested solutions were transferred to pre-conditioned $\left(24 \mathrm{~h}\right.$ in $10 \% \mathrm{v} / \mathrm{v} \mathrm{HNO}_{3}$ followed by three rinses in ultrapure water) polypropylene bottles and diluted to $25 \mathrm{~mL}$ with ultrapure water. Total copper concentration was measured by graphite furnace Atomic Absorption Spectroscopy using a Perkin Elmer AAnalyst600 with Zeeman background correction. Following manufacturer instructions, 5 $\mu \mathrm{L}$ of a matrix modifier $\left(\mathrm{Pd}+\mathrm{Mg}\left(\mathrm{NO}_{3}\right)_{2}\right)$ were injected into the graphite tube along with a $20 \mu \mathrm{L}$ aliquot of each sample. On each sediment sample analyzed for $\mathrm{Cu}$, water content and organic matter content as LOI (Loss on Ignition; Dean, 1974) were analyzed in duplicate by weight loss after ignition at $60^{\circ} \mathrm{C}$ for two days and $550^{\circ} \mathrm{C}$ for six $\mathrm{h}$.

Diatoms were prepared from cores $07 / 1 \mathrm{~B}$ and $07 / 2 \mathrm{~A}$ using standard $\mathrm{H}_{2} \mathrm{O}_{2}-\mathrm{HCl}$ digestion (Renberg, 1990) and mounted in Naphrax. On each slide, a minimum of 250 diatom valves were enumerated by light microscopy under phase contrast at 1000x (Zeiss Axioplan).

\section{RESULTS}

\section{Quality control}

Blank values for microwave assisted digestions ranged from below detection limit $\left(0.2 \mu \mathrm{g} \mathrm{L}^{-1}\right)$ to $7.4 \mu \mathrm{g} \mathrm{\textrm {L } ^ { - 1 }}$; the latter figure indicating some residual contamination after the digestion of samples with high $\mathrm{Cu}$ content. With one exception (blank signal equal to $8.4 \%$ of the sample signal), blank values were below $5 \%$ of sample signals (Supplementary Tab. 1). Analytical results (in $\mu \mathrm{g} \mathrm{L}^{-1}$ ) were corrected for the corresponding blank values before conversion to mass-based concentrations $\left(\mathrm{mg} \mathrm{kg}^{-1}\right)$. Concentrations for the reference material S7 ranged from 86.34 to $123.8 \mathrm{mg} \mathrm{kg}^{-1}$ d.w. with a mean recovery $(\mathrm{n}=9)$ of $94 \pm 12 \%$ (Supplementary Tab. 2).

\section{Copper pollution, loss on ignition and water content}

A detailed chronology of core 07/1A has been described by Piscia et al. (2012) who report accumulation rates between $0.0078 \mathrm{~g} \mathrm{~cm}^{-2} \mathrm{yr}^{-1}$ (from $5.5 \mathrm{~cm}$ to $3.5 \mathrm{~cm}$ ) and $0.0144 \mathrm{~g} \mathrm{~cm}^{-2} \mathrm{yr}^{-1}$ at $1.5 \mathrm{~cm}$. In the same core, mean (volumetric) sedimentation rates increased from $0.041 \mathrm{~cm}$ year ${ }^{-1}$ at $4.5 \mathrm{~cm}$ to $0.083 \mathrm{~cm}_{\text {year }}{ }^{-1}$ at $0.5 \mathrm{~cm}$. A sedimentation rate of $0.033 \mathrm{~cm}$ year $^{-1}$ is reported at $5.5 \mathrm{~cm}$. Using the Constant Rates of Supply (CRS) ${ }^{210} \mathrm{~Pb}$ dating model, Piscia et al. (2012) propose the following radiometric dates for core ORTA 07/1A: $2001(0.5 \mathrm{~cm}), 1989$ (1.5 $\mathrm{cm}), 1975(2.5 \mathrm{~cm}), 1957(3.5 \mathrm{~cm}), 1935(4.5 \mathrm{~cm})$, and $1909(5.5 \mathrm{~cm})$. Extrapolating the sedimentation rate of $0.033 \mathrm{~cm}$ year ${ }^{-1}$ to the core bottom dates the deepest section of the core at around $500 \mathrm{AD}$.

Copper concentrations were low and stable (from 34 to $52 \mathrm{mg} \mathrm{kg}^{-1}$ d.w.) between the core bottom and $10.5 \mathrm{~cm}$ (ca $1750 \mathrm{AD}$ ). Contamination by $\mathrm{Cu}$ started in 1927 (being first visible at $5.5 \mathrm{~cm}$ ), increased with time and peaked at $3.5 \mathrm{~cm}$ before declining again, albeit to levels about 30-fold higher than those observed at the core bottom (Fig. 2a). Water content decreased from $89 \%$ w.w. at the top of the core to $69 \%$ w.w. at $25.5 \mathrm{~cm}$ and remained around $70 \%$ w.w. down to the core bottom. Percent LOI content followed a similar trend (Supplementary Tab. 3), with values decreasing from $25 \%$ d.w. at the top of the core to about $12 \%$ d.w. at $25.5 \mathrm{~cm}$ and then stabilizing around $15 \%$ d.w. in the lowermost part of the core. For core $07 / 1 \mathrm{~A}$, percent LOI and water content were significantly correlated (Spearman $\mathrm{R}, \mathrm{P}<0.01, \mathrm{n}=10$ ) and $\mathrm{Cu}$ concentrations also correlated with the two variables ( $\mathrm{P}$ $<0.05$ ). No regression could be established between $\mathrm{Cu}$ concentrations and the other variables over the entire length of the core. However, $\mathrm{Cu}$ and percent LOI increased proportionally between $5.5 \mathrm{~cm}$ (1909 AD) and 3.5 $\mathrm{cm}(1957 \mathrm{AD}) ;$ i.e. the period between the entry into service of the rayon factory and the installation of a wastewater treatment plant to treat its effluent in 1958.

In core $07 / 2 \mathrm{~A}$, sediment accumulation rate ranged from a maximum of $0.27 \mathrm{~g} \mathrm{~cm}^{-2} \mathrm{y}^{-1}$ to a minimum of $0.029 \mathrm{~g} \mathrm{~cm}^{-2} \mathrm{y}^{-1}$ in the upper $13 \mathrm{~cm}$-section of core ORTA 07/2A (Piscia et al., 2016). In the deepest parts of the core 


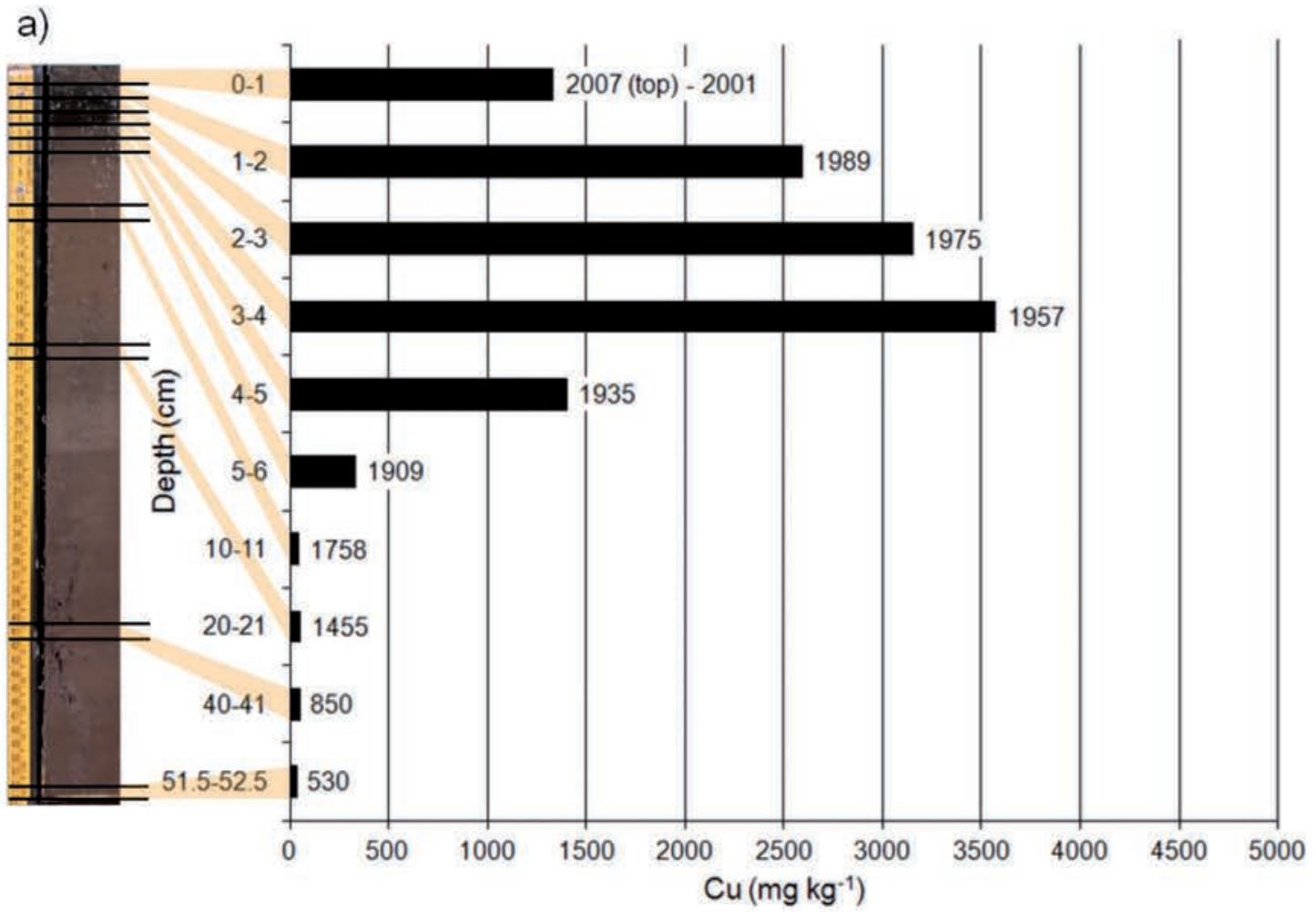

b)

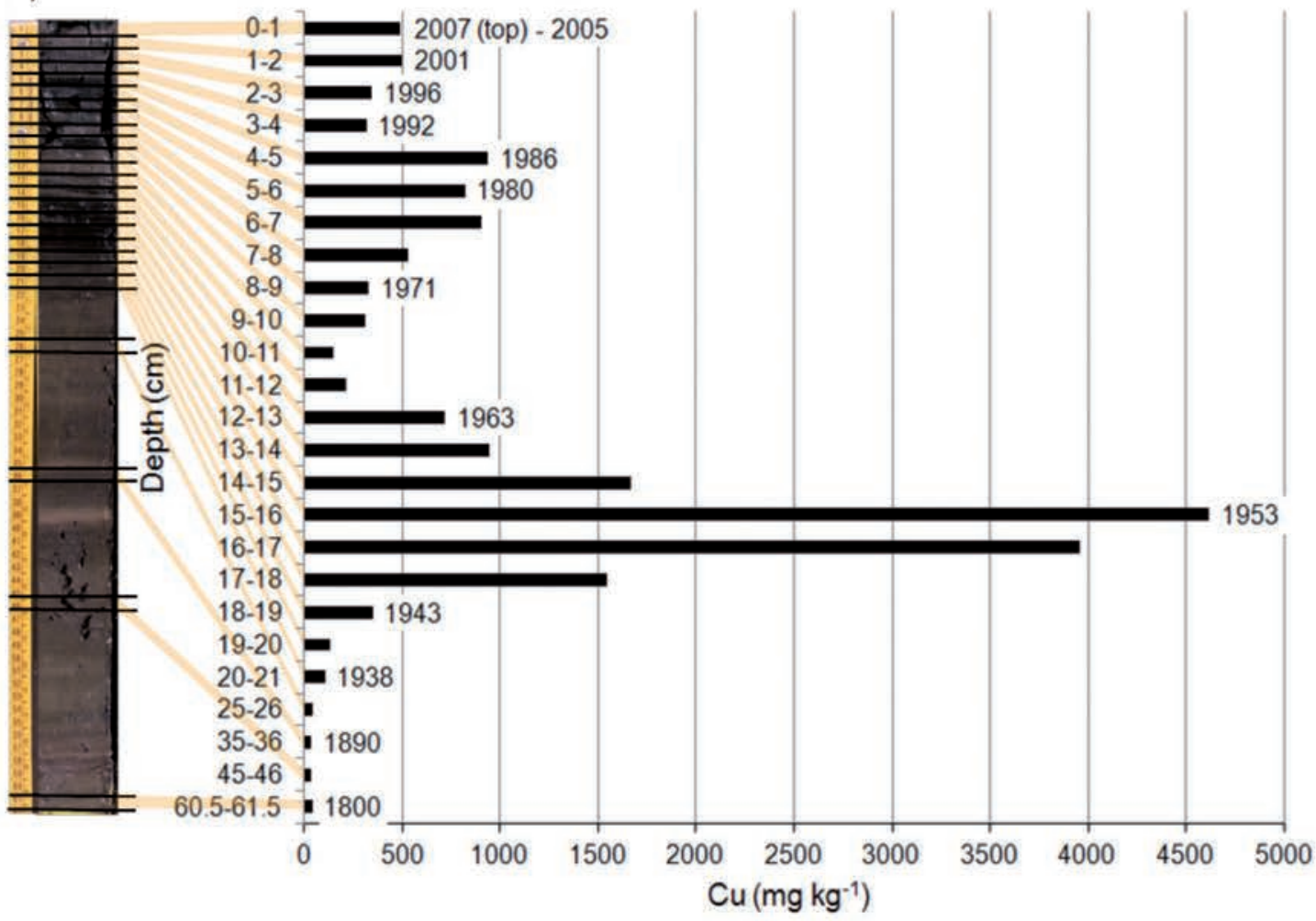

Fig. 2. Concentration profiles $\left(\mathrm{mg} \mathrm{kg}^{-1}\right)$ of total copper in sediment cores collected in $2007 \mathrm{in}$ : a) the southern part of lake Orta (core ORTA 07/1A); and b) the central part of lake ORTA (core ORTA 07/2A). Labels on the right-hand side of the bars indicate the estimated age (calendar years) of the corresponding sediment section. Pictures of the corresponding cores are shown on the right of each graph. Note that, in core ORTA $07 / 2 \mathrm{~A}$, the sedimentary record has been altered at a depth of about $14 \mathrm{~cm}$ (see text for details). 
$(13-61.5 \mathrm{~cm})$, sedimentation rate was around $0.29 \mathrm{~cm} \mathrm{y}^{-1}$ and unsupported ${ }^{210} \mathrm{~Pb}$ concentration declined exponentially with depth. Extrapolating the sedimentation rate of $0.29 \mathrm{~cm} \mathrm{yr}^{-1}$ to the core bottom, the base of the core should represent circa $1800 \mathrm{AD} .{ }^{210} \mathrm{~Pb}$ dates calculated by CRS model place 1986 at depth of $4.5 \mathrm{~cm}$ and 1963 at 12 $13 \mathrm{~cm}$, in good agreement with results of ${ }^{137} \mathrm{Cs}$ record (Piscia et al., 2016). Based on the available detailed chronology (Fig. 2b), deposition rates ranged between 0.17 and $0.25 \mathrm{~cm}$ year ${ }^{-1}$ between 1980 and 2007 and were somewhat higher $\left(0.27-0.50 \mathrm{~cm}\right.$ year $\left.{ }^{-1}\right)$ between 1800 and 1980 (Supplementary Tab. 4).

Copper concentrations in the deep sections of core ORTA 07/2A ranged between 31 and $43 \mathrm{mg} \mathrm{kg}^{-1}$ d.w. and were comparable to the levels observed in core ORTA 07/1 A for sections not impacted by anthropogenic activity. A moderate increase of $\mathrm{Cu}$ concentration (up to about 350 $\mathrm{mg} \mathrm{kg}^{-1}$ d.w.) occurred between 21 and $18 \mathrm{~cm}$; while between 18 and $16 \mathrm{~cm} \mathrm{Cu}$ levels raised abruptly to a maximum of about $4600 \mathrm{mg} \mathrm{kg}^{-1}$ d.w. Starting from the depth of $15 \mathrm{~cm}$ to the top of the core, the temporal evolution of $\mathrm{Cu}$ contamination did not follow a uniform trend suggesting that sedimentation was not homogeneous and material of different origin was reworked in this core. Copper concentrations decreased from $4,600 \mathrm{mg} \mathrm{kg}^{-1}$ at $15 \mathrm{~cm}$ to 150 $\mathrm{mg} \mathrm{kg}{ }^{-1}$ at $10 \mathrm{~cm}$, but increased again to about $950 \mathrm{mg} \mathrm{kg}^{-1}$ between 10 and $4 \mathrm{~cm}$. In the topmost $4 \mathrm{~cm}$ of the core, $\mathrm{Cu}$ concentrations fluctuated between 300 and $500 \mathrm{mg} \mathrm{kg}^{-1}$.

Water content and percent LOI also did not show a regular profile along core ORTA 07/2A (Supplementary Tab. 3). Water content increased from ca. $65 \%$ in the uppermost $4 \mathrm{~cm}$ to a maximum of ca. $80 \%$ between 4 and 8 $\mathrm{cm}$. Then it decreased again to $60 \%$ between 8 and $14 \mathrm{~cm}$ section, and increased to $80 \%$ between 14 and $21 \mathrm{~cm}$. Finally, in the deepest section $(>21 \mathrm{~cm})$ it was around $70 \%$, with two relative minima (at 25-26 and 60.5-61.5 cm). LOI was relatively high (ca. $20 \%$ of the dry weight) between 4 and $8 \mathrm{~cm}$ and between 14 and $18 \mathrm{~cm}$, but decreased to ca. $15 \%$ between 8 and $14 \mathrm{~cm}$. In core $07 / 2 \mathrm{~A}$, $\mathrm{Cu}$ concentrations and percent $\mathrm{LOI}$ were significantly correlated (Spearman $\mathrm{R}, \mathrm{P}<0.01, \mathrm{n}=25$ ).

\section{Diatom assemblages}

In core ORTA 07/1B, diatom profiles (Fig. 3a) fit well with a previously published core profile (Ruggiu et al., 1998) and with the known effects of water pollution on the diatom communites of Lake Orta, indicating regular sediment accumulation. In particular, in the lower part of the core, diatom assemblages were dominated by small centrics (Cyclotella comensis, Discostella stelligera and Handmannia bodanica) typical of deep oligotrophic lakes with stable stratification (Fig. 3a).

After the beginning of pollution, small centric diatoms declined and the diatom community was dominated by
Achnanthidium minutissimum and Fragilaria nanoides (identified as Synedra acus by Tonolli 1961, Synedra tenera by Ruggiu et al., 1998) (Fig. 3a). The former is a metal-tolerant taxon, generally reported as benthic (Potapova and Hamilton, 2007) and circumneutral (van Dam et al., 1994). In the recent period, the core profile showed an increase in the relative abundance of Asterionella formosa, C. comensis and Fragilaria crotonensis.

In core ORTA 2007/2A (collected in a deeper area with steeper slopes), the section dominated by $A$. minutissimum and F. nanoides (between 4 and $22 \mathrm{~cm}$ ) and representing the period of lake pollution, is split into two parts by another section $(8-14 \mathrm{~cm})$ which contains a large proportion of C. comensis (Fig 3b). It seems reasonable that the latter section represents older sediment material carried towards the deepest part of lake bottom by a slump.

\section{DISCUSSION}

\section{Temporal evolution of copper contamination}

In the southern part of Lake Orta (core 07/1A), Cu sediment concentrations follow well the known pollution history of the lake. The first increase in $\mathrm{Cu}$ level at $5.5 \mathrm{~cm}$ is dated at $1927 \mathrm{AD}$, in excellent agreement with the beginning of the activity of the rayon factory on the southern shore of the lake. The peak concentration (about $3500 \mathrm{mg}$ $\mathrm{kg}^{-1}$ ) at $3.5 \mathrm{~cm}$ corresponds to $1958 \mathrm{AD}$, just before the introduction of water treatment processes at the factory (Baudo and Beltrami, 2001). From 1958 to 2007, Cu concentrations declined because of the water treatment plant and its subsequent improvement in 1981 (Baudo and Beltrami, 2001). The decrease in $\mathrm{Cu}$ concentrations has apparently been faster between 1.5 and $0.5 \mathrm{~cm}$ than between 3.5 and $1.5 \mathrm{~cm}$. The halving of $\mathrm{Cu}$ concentration between $1989(1.5 \mathrm{~cm})$ and $2001-2007(0.5 \mathrm{~cm})$ may reflect, at least partly, the effect of liming operations that were carried out in 1989 as it is explained below.

Calderoni et al. (1993) report that about $85 \%$ of the $\mathrm{CaCO}_{3}$ added during liming operations (i.e., 12,580 tons out of 14,800 ) eventually dissolved in the water column. Considering the solubility of $\mathrm{CaCO}_{3}$ at a pH of 6.5 (value after liming), precipitation of part of the remaining $15 \%$ of the added $\mathrm{CaCO}_{3}$ (i.e., 2220 tons) could have been enough to contribute to reducing $\mathrm{Cu}$ levels in contaminated bottom sediments. Our calculations (see supporting information for the details) estimate that 1,477 tons of $\mathrm{CaCO}_{3}$ could have precipitated following liming operations. Assuming a $\mathrm{Cu}$ adsorption capacity of $0.015 \mathrm{~kg}$ of copper per ton of $\mathrm{CaCO}_{3}$ (Aziz et al., 2008), the precipitated $\mathrm{CaCO}_{3}$ could potentially have adsorbed a total of $22.15 \mathrm{~kg}$ of copper. This figure must be compared with a dissolved concentration of about $40 \mu \mathrm{g} \mathrm{L}^{-1} \mathrm{Cu}$ in the water column during the late 1980s (Camusso et al., 1989); resulting in a stock of dissolved $\mathrm{Cu}$ around $51.5 \mathrm{~kg}$ for the entire lake. 


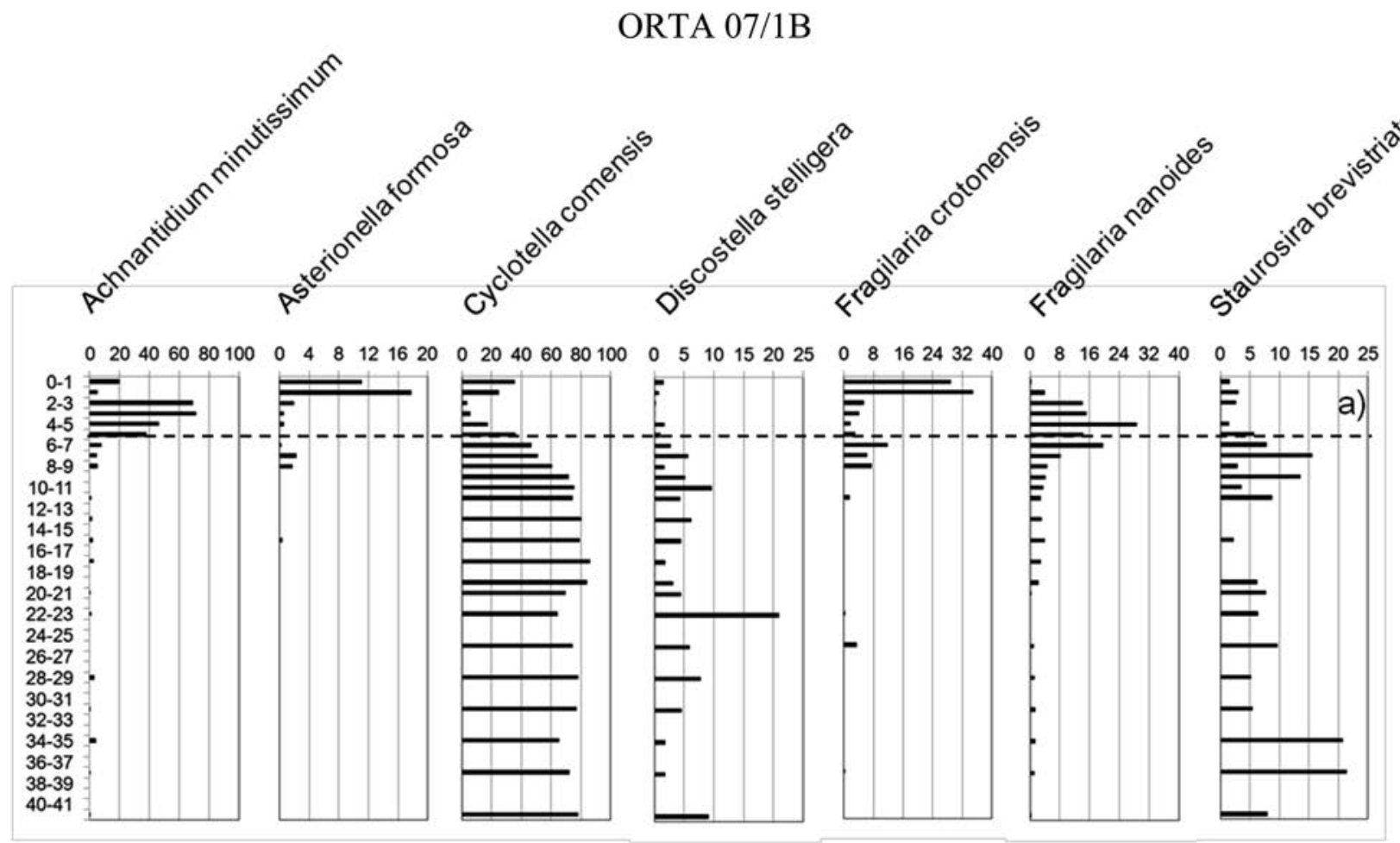

\section{ORTA 07/2A}

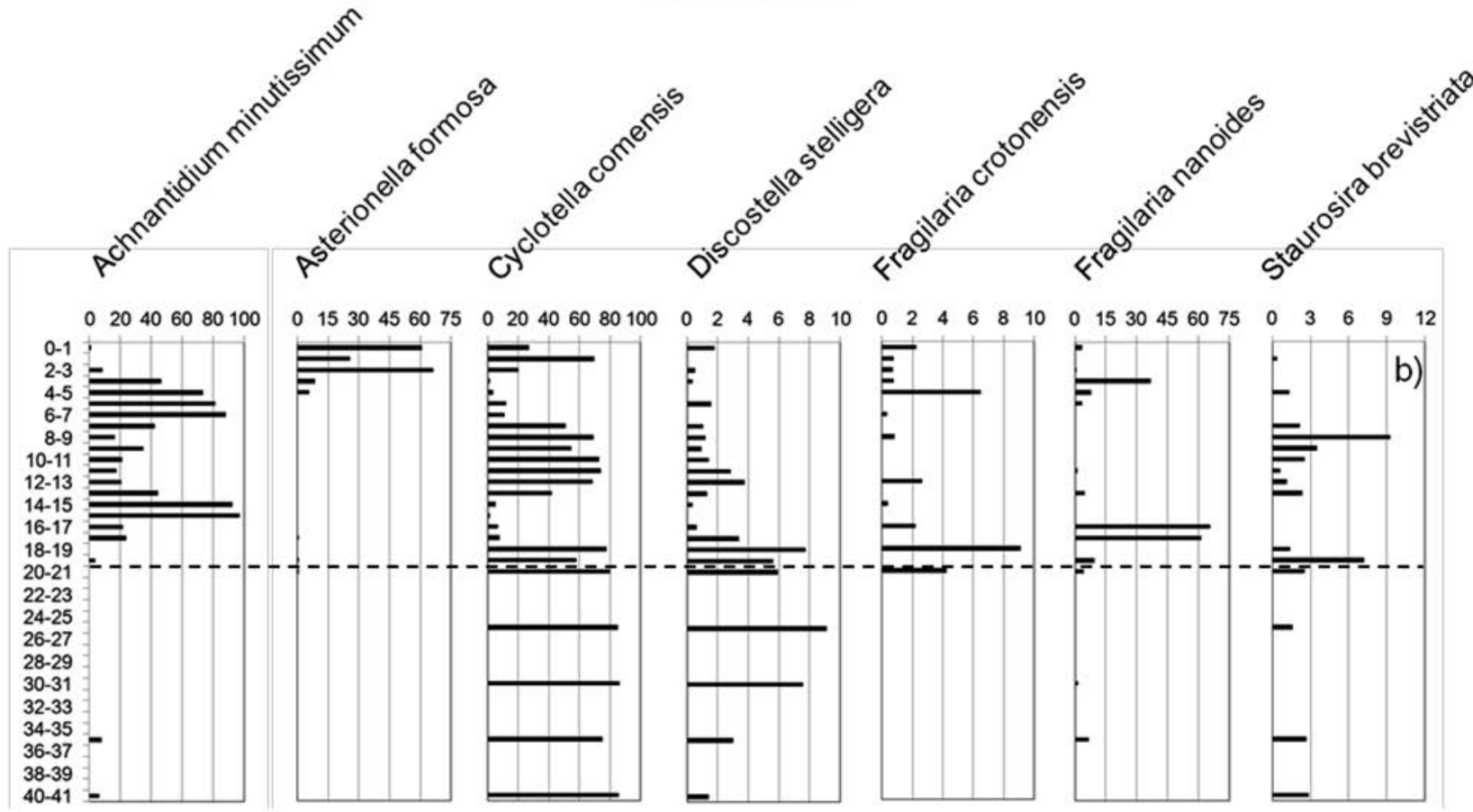

Fig. 3. Profiles of diatom percent abundances along cores ORTA 07/1B (a) and ORTA 07/2A (b). Abrupt decrease in the abundance of Cyclotella comensis and increase of the metal tolerant Achnanthidium minutissimum are observed after the onset of Cu pollution in the second half of the 1920s (dashed horizontal lines). Note that, in core ORTA 07/2A, the sedimentary record has been altered at a depth of about $14 \mathrm{~cm}$ (see text for details). 
In practice, the precipitating $\mathrm{CaCO}_{3}$ had the potential to adsorb about half of the dissolved $\mathrm{Cu}$ stock present in Lake Orta in pre-liming conditions. The other factor to consider is the contribution of the settling $\mathrm{CaCO}_{3}$ particles to the total sedimentation flux in Lake Orta. Considering a lake area of $18.2 \mathrm{~km}^{2}$ (and neglecting that liming was performed only on 2/3 of the lake surface; Camusso et al., 1989), we obtain: 1477 tons of precipitated $\mathrm{CaCO}_{3} / 18.2 \times 10^{-6} \mathrm{~m}^{2}$ (surface of Lake Orta) $=81.15 \mathrm{~g} \mathrm{~m}^{2}$ of precipitated material. This figure is comparable with the annual particulate flux of $243 \mathrm{~g} \mathrm{~m}^{-2}$ year-1 $^{-1}$ reported by Camusso et al. (1989). These calculations support the hypothesis that deposition of $\mathrm{CaCO}_{3}$ with relatively low $\mathrm{Cu}$ content could have contributed to decrease $\mathrm{Cu}$ levels in sediments after liming. In favour of the same hypothesis, Baudo and Beltrami (2001) report that the Ca content of the upper 2-cm of sediment grab samples collected in 1996 (post-liming) showed an increased content of Ca compared with 1985 (pre-liming) samples.

After liming, the extremely slow sedimentation rate in this part of the lake results in contaminated sediments being covered by unpolluted material at a very slow pace and, hence, persisting contamination. We notice that results from core 07/1 A do not agree with the post-liming increase in $\mathrm{Cu}$ concentration reported by Baudo and Beltrami (2001) in the southern part of Lake Orta. This discrepancy may partly arise from methodological issues. Baudo and Beltrami (2001) could not observe $\mathrm{Cu}$ enrichment when comparing pre-liming (1985) Ponar grab samples (collecting the top $10-15 \mathrm{~cm}$ of sediments) with post-liming (1992) grab samples or 10-cm core sections. An increase in sedimentary Cu levels between pre- (1985) and post-liming period was observed for sediment samples collected in 1996 when only the topmost $2-\mathrm{cm}$ of grab samples were retained for analysis (Baudo and Beltrami, 2001). According to the results of the present study, a $10-\mathrm{cm}$ thick sediment section in the southern part of Lake Orta could cover a period of over 200 years, thus representing a mix of polluted and unpolluted sediments (Fig. 2a). In such situation, the $\mathrm{Cu}$ content of homogenised grab or core samples collected in 1985 and 1992 could have been partially lowered by the presence of material not impacted by anthropogenic $\mathrm{Cu}$ pollution, thus leading to the observation of $\mathrm{Cu}$ enrichment in the 1985 vs 1996 comparison. On the other hand, Baudo and Beltrami (2001) also examined the distribution of $\mathrm{Cu}$ contamination in sediments over the whole Lake Orta and reported completely different $\mathrm{Cu}$ patterns for the two periods. Most notably, the highest $\mathrm{Cu}$ concentrations were recorded in the northern part of the lake in 1985 and in the southern part in 1996. Finally, Guilizzoni et al. (2001) reported variable mean sedimentation rates in the southern part of the basin. All considered, while the use of homogenised sediment samples can be (partly) useful for ecotoxicological purposes considering that biota can penetrate to different depth into the sediments, the study of $\mathrm{Cu}$ levels should be performed with the best possible resolution to follow the evolution of contamination.

While the exact age of the bottom sediment slice $(51.5-52.5 \mathrm{~cm})$ of core 07/1A cannot be established with certainty, $\mathrm{Cu}$ levels measured between 51.5 and $10 \mathrm{~cm}$ are similar and likely correspond to the background concentration of the sediment. Levels of $\mathrm{Cu}$ at the core bottom are comparable with those measured in old (1100-1300 $\mathrm{AD})$ and recent (2006 AD) sediments in the nearby Lake Maggiore (Vignati and Guilizzoni, 2011), further supporting the hypothesis that background $\mathrm{Cu}$ levels in Lake Orta are around 30-50 $\mathrm{mg} \mathrm{kg}^{-1}$ d.w.

The pollution history of the lake is also faithfully reflected in the diatom assemblages present in core 07/1B. After the beginning of pollution, the rapid decline of $C$. comensis, typical of oligotrophic lakes, was accompanied by the increase of $A$. minutissimum (Fig. 3a) which is a metal-tolerant taxon. In Lake Orta, this taxon is epilithic (van Dam and Mertens, 1990) and epiphytic (Cattaneo, 1992), but it was and is, together with other less important congeneric species, a constant component of the plankton even when water $\mathrm{pH}$ was around 4 units (Ruttner, 1959; Vollenweider, 1963, with a taxonomic confirmation by F. Hustedt and by A. Cleve-Euler). In the top section of core 07/1B, the increase in the abundances of $A$. formosa, $C$. comensis and F. crotenensis indicates the recovery of Lake Orta towards its original, pre-pollution conditions. While there are no systematic phytoplankton studies in Lake Orta before 1926, the diatom community in the pre-pollution sections of the core is very similar to the one found at that time in neighboring, deep lakes Maggiore (Marchetto et al., 2004), Como and Iseo (Marchetto and Bettinetti, 1995). The species in the upper part of core 07/1B are those typical of present phytoplankton assemblages in similar lakes, such as Lake Maggiore (Marchetto et al., 2004), and may reasonably represent present diatom assemblages in Lake Orta.

In the central and deeper part of the lake, sedimentation is faster than in the southern part and the $60 \mathrm{~cm}$ core ORTA 07/2A covers a period of approximately 200 years from $1800 \mathrm{AD}$ to 2007 (Fig. 2b). Copper levels remained between 30 and $40 \mathrm{mg} \mathrm{kg}^{-1}$ up to section $25-26 \mathrm{~cm}$, corresponding to ca. 1920. Copper levels started to increase from section $20-21 \mathrm{~cm}(1938 \mathrm{AD})$ as a consequence of anthropogenic inputs in the southern part of the lake. Peak values of over $4500 \mathrm{mg} \mathrm{kg}^{-1}$ were observed in the early 1950 s, in good agreement with the known anthropogenic sources of $\mathrm{Cu}$ and with the period of maximum contamination in the core $07 / 1 \mathrm{~A}$. After this absolute maximum at the depth of $15.5 \mathrm{~cm}, \mathrm{Cu}$ concentrations rapidly decreased to about $150 \mathrm{mg} \mathrm{kg}^{-1}$ (at $10.5 \mathrm{~cm}$ ) in the time span of about 15 years (Fig. 2b). While this decrease is compatible with 
the introduction of effluent treatment at the rayon factory in 1958, the sharp decrease in $\mathrm{Cu}$ concentration between $15-16 \mathrm{~cm}$ (about $4600 \mathrm{mg} \mathrm{kg}^{-1}$ ) and $10-11 \mathrm{~cm}$ (about 150 $\mathrm{mg} \mathrm{kg}^{-1}$ ) may also reflect sudden inputs of eroded soil material following the floods that interested the lake basin in 1963 and 1965 (Guilizzoni et al., 2001). Two independent proxies support this interpretation: first, in the diatom profile, these sections are rich in C. comensis (a species typical of the period before pollution, Fig. $3 \mathrm{~b}$ ) and this pattern is not shared with core $07 / 1 \mathrm{~B}$, nor with previous cores (Ruggiu et al., 1998). Second, a minimum of LOI percentage occurs in this part of the core (Supplementary Tab. 3), suggesting the input of mineral material carried by the floods. Furthermore, the ranges of copper and organic matter percentage in sediments collected in the littoral zone of Lake Orta in 1969 were $210-237 \mathrm{mg} \mathrm{kg}^{-1}$ and $1.1-4.9 \%$, respectively (Chiaudani, 1969). Otherwise stated, slumps bringing inputs of littoral sediments to the lake bottom had the potential to dilute contaminated sediments deposited under normal conditions.

Because of the higher sedimentation rate, $\mathrm{Cu}$ contamination in this part of the lake has decreased faster than in the southern part, but $\mathrm{Cu}$ levels remained around $500 \mathrm{mg}$ $\mathrm{kg}^{-1}$ d.w. in 2007; i.e. 10-15-fold above background. Furthermore, at the end of the 1950 s, several galvanic industries entered into service in the basin of the River Lagna (Fig. 1) and could contribute to $\mathrm{Cu}$ discharge in the central part of the lake. Copper input from these activities seems to have offset the water treatment improvement in the rayon factory considering that $\mathrm{Cu}$ levels in section 13-14 cm (1960 AD) and 4-5 cm (1986 AD) are comparable. Liming operations have not left a mark of increased $\mathrm{Cu}$ deposition in this part of the lake either, in agreement with Baudo and Beltrami (2001) who did not observe post-liming increases in $\mathrm{Cu}$ concentrations in the central part. All considerations made with regard to core $07 / 1 \mathrm{~A}$ are valid, but the higher sedimentation rates in the central part of the basin make the comparison of homogenized grab samples and top sediment sections of cores less problematic. Finally, Cu levels at the top of core ORTA 07/2A for 2007 were higher than those measured for the 1990s indicating that further monitoring of dated sediment cores is needed to verify the most recent trends. Indeed, results for cores 07/1 A and 07/2A compare well with previous studies, suggesting that they are representative of the recent evolution of the basin between the late 1990s and 2007.

In 1985, Baudo et al. (1989) collected 57 grab sediment samples covering approximately $30-40$ years and concluded that concentrations (observed range 1.88-3598 $\mathrm{mg} \mathrm{kg}^{-1} \mathrm{~d}$.w.) were decreasing compared with earlier studies. Between 1994 and 1997, Beltrami et al. (1999) collected cores at several locations including Buccione and Tortirogno (Fig. 1). In the Buccione core (25 cm long), $\mathrm{Cu}$ levels ranged from $71 \mathrm{mg} \mathrm{kg}^{-1} \mathrm{~d}$.w. at the core bottom to $3433 \mathrm{mg} \mathrm{kg}^{-1}$ d.w. at $6-8 \mathrm{~cm}$ and $865 \mathrm{mg} \mathrm{kg}^{-1}$ d.w. at the top of the core. In absolute terms, minimum, maximum and surface values are comparable with those measured in core $07 / 1 \mathrm{~A}$, suggesting that decrease in $\mathrm{Cu}$ concentration in the southern part of Lake Orta slowed down or stopped between 1997 and 2007. Cu levels at the bottom of the Tortirogno core were around 30-40 mg kg-1 d.w., indicating that sediments between 20 and $12 \mathrm{~cm}$ depth were unaffected by $\mathrm{Cu}$ anthropogenic pollution. In the same core, maximum and top (1997) $\mathrm{Cu}$ concentrations were about 1400 and $1000 \mathrm{mg} \mathrm{kg}^{-1}$ d.w., respectively. In this case, a direct comparison with core ORTA 07/2A is not straightforward. In another core collected in the zone of Pettenasco (Fig. 1) at a depth of $120 \mathrm{~m}$ (Guilizzoni et al., 2001), maximum and surface (1992 AD) Cu levels were over $3000 \mathrm{mg} \mathrm{kg}^{-1} \mathrm{~d} . \mathrm{w}$. and around $1000 \mathrm{mg}$ $\mathrm{kg}^{-1}$ d.w., respectively. The latter value agrees well with section $4-5 \mathrm{~cm}$ of core ORTA07/2A, the section being dated at 1986. In general, the sedimentation pattern appears somehow disturbed in the central part of the lake. However, decrease in $\mathrm{Cu}$ levels seems to have slowed down also in this zone between 1997 and 2007. Overall, legacy contamination persists; especially in the southern part of the lake because the low input rate of clean material leaves old, contaminated sediments exposed at the interface with the water column.

Differences observed between cores 07/1 A and 07/2A mostly seem to originate from disturbances in the sedimentation pattern in the central part of the lake (core 07/2A). It is noteworthy that changes in the $\mathrm{Cu}$ profiles of the two cores are in good agreement during the contamination phase, but not after the contamination peak of the late 1950s. During the contamination phase, the increase in $\mathrm{Cu}$ sedimentary concentration is slightly delayed in core 07/2A (between 1938 and 1943; Fig. 2b) compared with core 07/1A (between 1909 and 1935; Fig. 2a) and may simply reflect the distance of the sites from the main contamination sources at that time. Peak contamination values were reached in the mid 1950s at both sites and were even higher at $07 / 2 \mathrm{~A}$ possibly because finer sediments were trapped in the central basin. As already mentioned, the sedimentary record of core $07 / 2 \mathrm{~A}$ was then perturbed either by the occurrence of slumps bringing littoral sediments with low $\mathrm{Cu}$ content to the lake bottom or by inputs of uncontaminated material following the historical floods of 1965-1963 (Guilizzoni et al., 2001). In the meanwhile, the reduced input of $\mathrm{Cu}$ from the rayon factory and the opening of other $\mathrm{Cu}$-discharging activities in the basin of the river Lagna (Fig. 1) may have changed the pattern of $\mathrm{Cu}$ deposition in Lake Orta. In this scenario, most $\mathrm{Cu}$ discharges would have preferentially reached the central part of the basin and increased $\mathrm{Cu}$ concentrations in core 07/2A between the end of the 1960s and 1986 (Fig. 2b). At the opposite, after the peak Cu levels at the end of the 1950s, 
sediments in the southern part of the lake began to be slowly covered by material with low $\mathrm{Cu}$ levels resulting in a continuous, albeit slow, decrease in $\mathrm{Cu}$ concentration in core $07 / 1 \mathrm{~A}$. The abrupt decrease between 1986 and 1992-1996 could be due to the deposition of $\mathrm{CaCO}_{3}$ following the liming period as previously explained for core 07/1 A. Baudo and Beltrami (2001) actually report an increased Ca content between pre- (1985) and post-liming (1996) sediment material; which could be a proxy for increased carbonate content in sediments. In the case of a major constituent such as calcium, the methodological issues associated with the use of homogenized sediment samples are likely less important than for $\mathrm{Cu}$.

At present, we are unable to ascribe the persistence of $\mathrm{Cu}$ contamination in bottom sediments of Lake Orta to the presence of $\mathrm{Cu}$ inputs from its tributaries or to early diagenetic processes at the sediment-water interface. The average $\mathrm{Cu}$ content for suspended particulate matter (SPM) collected in Lake Orta during the period 2012-2013 was $1180 \pm 570 \mathrm{mg} \mathrm{kg}^{-1}$ d.w., comparable with the levels of $1250 \pm 750 \mathrm{mg} \mathrm{kg}^{-1}$ measured for the neighbouring Lake Maggiore (Casati, 2013). In the case of Lake Maggiore, $\mathrm{Cu}$ concentrations in bed sediments were around $60 \mathrm{mg}$ $\mathrm{kg}^{-1}$ d.w. during the period 2002-2006 (Vignati and Guilizzoni, 2011) and in the range $60-100 \mathrm{mg} \mathrm{kg}^{-1}$ d.w. in the uppermost section of sediment cores collected in 2008 (CIPAIS, 2009). Considering the similar $\mathrm{Cu}$ concentrations in SPM of lakes Maggiore and Orta and the low dissolved
$\mathrm{Cu}$ concentrations (about $2 \mu \mathrm{g} \mathrm{L}^{-1}$ ) in Lake Orta (Casati, 2013), inputs from tributaries would rather contribute to a decrease in $\mathrm{Cu}$ contamination in Lake Orta sediments. The persistence of elevated $\mathrm{Cu}$ concentrations in sediments of Lake Orta over the period 1997-2007 is therefore likely caused by early diagenetic processes at the sediment-water interface and, especially in core $07 / 1 \mathrm{~A}$, very low sedimentation rates. This issue would however benefit from direct investigation in the future.

\section{Ecotoxicological implications of copper contamination}

While the most recent trends of $\mathrm{Cu}$ geochronology require further study, 2007 copper levels in Lake Orta sediments remained comparable to, or higher than, toxic threshold determined in various studies using both artificial and natural $\mathrm{Cu}$-spiked sediments (Tab. 1). Using artificial spiked sediments, Roman et al. (2007) established thresholds of $50 \%$ mortality (LC50, lethal concentrations killing $50 \%$ of exposed organisms) at values between 150 and $327 \mathrm{mg} \mathrm{kg}^{-1} \mathrm{~d}$.w. for different sediment-dwelling organisms (Tab. 1), with corresponding No Observed Effect Concentration (NOEC) always below $180 \mathrm{mg} \mathrm{kg}^{-1}$ d.w. Lower Effective Concentrations (EC50) and NOEC values were obtained when growth was considered as an endpoint. However, Cairns et al. (1984) reported EC50 above $2,000 \mathrm{mg} \mathrm{kg}^{-1}$ d.w. for the survival of $C$. tentans in spiked natural sediments (Tab. 1), cautioning about the direct ap-

Tab. 1. Compilation of ecotoxicological data for No Observed Effect Concentrations (NOEC), Lowest Observable Effect Concentrations (LOEC), half maximal Lethal Concentrations (LC50) or Effective Concentrations (EC50) for tests with Cu-spiked sediments. All values are in $\mathrm{mg} \mathrm{Cu} \mathrm{kg}^{-1}$ sediment d.w.

\begin{tabular}{|c|c|c|c|c|c|}
\hline Species & Endpoint & NOEC & LOEC & LC50 or EC50 & Matrix \\
\hline \multirow[t]{8}{*}{ Tubifex tubifex } & Survival (28 d) & 138 & 158 & 327 & A \\
\hline & Survival (14d) & n.a. & n.a. & $375 \pm 148.7$ & $\mathrm{~B}$ \\
\hline & Survival (28d) & n.a. & $109-(>802)$ & n.a. & $\mathrm{D}$ \\
\hline & Growth (28 d) & 78.3 & 102 & 126 & $\mathrm{~A}$ \\
\hline & Growth(28d) & n.a. & n.a. & $288 \pm 22$ & $\mathrm{~B}$ \\
\hline & Reproduction (28d) & n.a. & n.a. & $183 \pm 12.7$ & $\mathrm{~B}$ \\
\hline & Reproduction (28d) & n.a. & $69-(>802)$ & n.a. & $\mathrm{D}$ \\
\hline & Reproduction (28d) & n.a. & $92-129$ & $81-107$ & $\mathrm{E}$ \\
\hline \multirow[t]{3}{*}{ Hyalella azteca } & Survival (14 d) & 100 & 180 & 316 & A \\
\hline & Survival (10 d) & n.a. & n.a. & $1078(922-1259)$ & $\mathrm{C}$ \\
\hline & Growth (28 d) & 53.2 & 95,4 & 194 & A \\
\hline \multirow[t]{2}{*}{ Chironomus riparius } & Survival (14d) & $<180$ & 180 & 320 & A \\
\hline & Growth (28d) & 89.2 & 188 & 150 & A \\
\hline \multirow[t]{2}{*}{ Chironomus tentans } & Survival (10 d) & n.a. & n.a. & $2296(1690-3119)$ & $\mathrm{C}$ \\
\hline & Survival (10 d) & n.a. & n.a. & 857 (685-1073) & $\mathrm{C}$ \\
\hline Lumbriculus variegatus & Survival & 114 & 140 & 211 & A \\
\hline \multirow[t]{2}{*}{ Gammarus pulex } & Survival (35d) & 94.7 & 176 & 151 & A \\
\hline & Growth (35d) & 94.7 & 176 & 148 & A \\
\hline Gammarus lacustris & Survival (10 d) & n.a. & n.a. & $964(777-1196)$ & $\mathrm{C}$ \\
\hline
\end{tabular}

A, spiked artificial sediments (Roman et al., 2007); B, spiked natural sediment (Méndez-Fernández et al., 2013); C, spiked natural sediments (Cairns et al., 1984); D, spiked natural sediments (Vecchi et al., 1999); E, reconstructed spiked sediment (Pasteris et al., 2003); n.a., not available from the original study 
plicability to real field situation of results obtained using formulated sediments.

Indeed, actual toxicity is controlled by the specific copper-binding properties of sediments rather than by the sedimentary Cu concentration alone. Simpson (2005) calculated an LC50 for the amphipod Melita plumulosa exposed to copper equal to $163 \mathrm{mg} \mathrm{kg}^{-1} \mathrm{~d}$.w. for a sediment with low complexing capacity $\left(\mathrm{K}_{\mathrm{d}}=1 \times 10^{3} \mathrm{~L} \mathrm{~kg}^{-1}\right), 825$ d.w. $\mathrm{mg} \mathrm{kg}^{-1}$ d.w. for intermediate complexing capacity $\left(\mathrm{K}_{\mathrm{d}}=1 \times 10^{4} \mathrm{~L} \mathrm{~kg}^{-1}\right)$ and $1400 \mathrm{mg} \mathrm{kg}^{-1} \mathrm{~d}$.w. for highly complexing sediments $\left(\mathrm{K}_{\mathrm{d}}=1 \times 10^{5} \mathrm{~L} \mathrm{~kg}^{-1}\right)$. In the past, $\mathrm{Cu}$ occurred mainly in the dissolved phase (Camusso et al., 1989) and aqueous exposure controlled toxic effects for organisms. At present, dissolved $\mathrm{Cu}$ concentrations have decreased below $2 \mu \mathrm{g} \mathrm{L}^{-1}$ (Casati, 2013) so that the importance of dietary uptake for benthic organisms from sediment ingestion, and hence the importance of residual $\mathrm{Cu}$ contamination in sediments, is likely higher than in the past. However, no recent data on $\mathrm{Cu}$ distribution between pore water and sediment solids in Lake Orta are available to confirm this hypothesis. The lithology of cores $07 / 1 \mathrm{~A}$ and $07 / 2 \mathrm{~A}$ excluded the massive presence of sandy sediments with low complexing capacity and copper partition coefficients between $1 \times 10^{4}$ and $1 \times 10^{5} \mathrm{~L} \mathrm{~kg}$ ${ }^{1}$ should be the most realistic. This hypothesis compares favourably with the $\mathrm{K}_{\mathrm{d}}$ values between $3.1 \times 10^{4} \mathrm{~L} \mathrm{~kg}^{-1}$ and $6.1 \times 10^{4} \mathrm{~L} \mathrm{~kg}^{-1}$ reported for $\mathrm{Cu}$ in the water column of Lake Orta (depth $140 \mathrm{~m}$, northern basin) during the period 1985-1987 (Camusso et al., 1989). Caution is clearly needed when comparing the post-liming situation in sediments deposited after 1988 and the pre-liming conditions examined in Camusso et al. (1989). Indeed, Casati (2013) reported even higher $\mathrm{K}_{\mathrm{d}}$ values for $\mathrm{Cu}$ partitioning in the water column (an average of $9.3 \times 10^{5} \mathrm{~L} \mathrm{~kg}^{-1}$ ) for the period 2012-2013. On the other hand, Baudo and Beltrami (2001) examined $\mathrm{Cu}$ concentrations in sediment cores and associated pore waters collected in 1992. Using the reported concentrations values, we could estimate a $\mathrm{K}_{\mathrm{d}}$ for $\mathrm{Cu}$ between 0.4 and $1 \times 10^{3} \mathrm{~L} \mathrm{~kg}^{-1}$. We notice that, in the case of these partition coefficients for sediments, dissolved concentrations were obtained analyzing pore waters recovered by centrifugation instead of filtration as in the case of samples collected in the water column. This methodological difference may also be the cause of the lower $\mathrm{K}_{\mathrm{d}}$ of $\mathrm{Cu}$ between sediments and pore waters compared with those between suspended particulate matter and the water column.

Considering all this information, copper concentration expected to cause $50 \%$ mortality in benthic organisms can be estimated between 800 and $1400 \mathrm{mg} \mathrm{kg}^{-1}$ d.w. based on the findings of Simpson (2005). With a different approach, Campana et al. (2013) determined a safe $\mathrm{Cu}$ concentrations of $5.5 \mathrm{mg} \mathrm{Cu} \mathrm{g}^{-1}$ organic carbon for the sediment fraction $<63 \mu \mathrm{m}$. We estimated organic carbon (OC) con- tent in our sediment samples by multiplying LOI by 0.4 (Supplementary Tab. 3) according to the observations of Lami et al. (2000) who observed OC to represent between 35 and $45 \%$ of LOI. In 2007, normalized Cu concentrations in surface $(0-5 \mathrm{~cm})$ Lake Orta sediments were between 13 and $36 \mathrm{mg} \mathrm{Cu} \mathrm{g}^{-1} \mathrm{OC}$ in core 07/1 $\mathrm{A}$ and 4.5-9.5 $\mathrm{mg} \mathrm{Cu} \mathrm{g}^{-1} \mathrm{OC}$ in core 07/2A. The corresponding values for sediments with background $\mathrm{Cu}$ levels were between 0.05 and $1 \mathrm{mg} \mathrm{Cu} \mathrm{g}^{-1}$ OC (Supplementary Tab. 3). Thus, the potential for chronic toxicity may exist, but the actual $\mathrm{Cu}$ concentrations not posing risks to organisms dwelling in sediments of Lake Orta should be verified with site-specific studies.

The toxic potential of Lake Orta sediments has actually been documented by various studies published between the late 1990s and early 2000s. Sediments collected at three stations in the southern, central and northern parts of the lake in 1994-1997 were tested for phytotoxicity using commercially available seeds (Cucumis sativus, Lactuca sativa, and Lepidium sativum) (Beltrami et al., 1999). The germination index (GI) of the three plant species was determined after $72 \mathrm{~h}$ of incubation on dried sediment material (2-cm thick sediment sections) covered with filter paper and re-wetted with deionised water. A statistically significant reduction of the GI was observed for sediment sections containing over $1000 \mathrm{mg} \mathrm{kg}^{-1}$ d.w. of $\mathrm{Cu}$, but also in less contaminated sediments. Sediment toxicity was also tested in situ by caging individuals of Daphnia obtusa and Echinogammarus stammeri in contact with the sediments at $10 \mathrm{~m}$ depth for $48 \mathrm{~h}$ (Rossi and Beltrami, 1998). Organisms were brought back to the laboratory, maintained and counted till their death. The mortality of organisms exposed to sediments for 48 hours was significantly higher than controls, although year-to-year variations were observed. Burton Jr. et al. (2001) assessed sediment contamination using 6 toxicity assays on sections of 20-cm long sediment cores collected in 1994, four years after liming, at Omegna, at station 45 (central part of the lake and comparable to ORTA 07/2A) and Buccione (comparable to ORTA 07/1A) (Fig. 1). The top sediment layers (1994) were less toxic to D. magna ( $85 \%$ survival) and Hyalella azteca ( $85 \%$ survival) than intermediate layers. Complete mortality was observed between 4 and 20 $\mathrm{cm}$ for sediments collected in the central part of the lake. At the community level, Baudo et al. (2001) examined the benthos of Lake Orta in 51 stations distributed throughout the lake in 1996. While sediments hosted a variety of organisms, Baudo et al. (2001) observed that the chironomid community probably remained the same present before liming and that numerical abundances of macrofauna often remained lower than those typical of unpolluted freshwater environments. On the other hand, no clear correlation could be found between the level of sediment contamination and the presence/absence of the 
three most represented taxa: Tubifex tubifex, Chironomus thummi, and Procladius sp. The possibility of adaptation of benthic organisms to metals does indeed make sense (Ponti et al., 2010; Fischer et al., 2013; Piscia et al., 2015), considering that individuals of Tubifex tubifex were reported to be present in Lake Orta sediments even during the 1980s (Nocentini et al., 2001). However, Nocentini et al. (2001) surmised that contamination of water and sediments could still influence the colonisation of Lake Orta by macrobenthic organisms in 1993-1994.

Extrapolation of previous ecotoxicological knowledge to the present situation is not straightforward because of the changing exposure scenarios linked to the limnological evolution of Lake Orta. Despite chemical recovery, Lake Orta remains a vulnerable ecosystem with regard to populations of pelagic invertebrates (Ponti et al., 2010; Piscia et al., 2015), but no analogous information is available for benthic organisms. In particular, knowledge of $\mathrm{Cu}$ bioavailability from the dietary pathway is the most prominently missing piece of the puzzle to understand whether $\mathrm{Cu}$ contamination in Lake Orta sediments remains of concern or not. Past ecotoxicological studies do not provide direct information on the contribution of dietary $\mathrm{Cu}$ to toxicity because only epibenthic $(H$. azteca) or pelagic (D. obtusa) organisms were tested (Burton et al., 2001; Rossi and Beltrami, 1998). Although laboratory tests may not be able to fully catch long-term toxic effects on long-lived organism in field conditions, Besser et al. (2015) report a significant relationship between percentage amphipod survival in standard tests and invertebrate taxa richness in the Vermont copper belt. However, findings from laboratory tests may not directly apply to real field situations (Ferrari et al., 2014). Studies on the bioavailability and toxicity of copper contained in sediments of Lake Orta should therefore use a combination of conventional and in-situ approaches.

\section{CONCLUSIONS}

Sediments of Lake Orta have faithfully recorded the onset of $\mathrm{Cu}$ contamination in the 1920 s, as well as the events leading to a progressive decrease of $\mathrm{Cu}$ loading to the lake, both in the southern and in the central part of the basin. In the southern part of Lake Orta, $\mathrm{Cu}$ concentrations have been regularly decreasing since the peak levels of $3500 \mathrm{mg} \mathrm{kg}^{-1}$ d.w. measured in the $1950 \mathrm{~s}$. The extremely low sedimentation rates in this part of the lake do however prevent a fast recovery of sediments from past contamination and $\mathrm{Cu}$ levels were still above $1000 \mathrm{mg} \mathrm{kg}^{-}$ ${ }^{1} \mathrm{~d}$.w in 2007. In the central part of the lake, $\mathrm{Cu}$ concentrations also peaked at about $4500 \mathrm{mg} \mathrm{kg}^{-1}$ d.w. in the late 1950s and had decreased to $500 \mathrm{mg} \mathrm{kg}^{-1}$ d.w. in 2007. The decrease of $\mathrm{Cu}$ concentration in the central basin of Lake Orta could have been facilitated by the occurrence of turbidites which, in this zone, is documented by the changes in the composition of the fossil diatom communities. Liming operations performed at the end of the 1980s could also have contributed to lower $\mathrm{Cu}$ concentration in sediments. About $15 \%$ of the $\mathrm{CaCO}_{3}$ added for liming (about 1500 tons) could actually have precipitated and contributed to reduce $\mathrm{Cu}$ concentrations in bed sediments.

Despite an improved situation compared with the preliming period, $\mathrm{Cu}$ levels remain high enough to be of potential concern in terms of ecotoxicity to sediment-dwelling organisms in both the southern and central basin of Lake Orta. Particular attention should be given to understand the effects of dietary ingestion of $\mathrm{Cu}$ from sediments which, unlike in previous ecotoxicological studies, may now represent the main route of $\mathrm{Cu}$ exposure for sediment-ingesting benthic organisms. Information is also needed on present $\mathrm{Cu}$ behaviour (e.g., partitioning between sediments and associated pore waters) as a function of sediment characteristics and on the actual bioavailability of $\mathrm{Cu}$ in order to rule out subtle and lasting effect on benthic organisms and communities. Other in situ phenomena, e.g. the occurrence of slumps causing massive mixing of sediments with different ages and degrees of contamination, cannot be modelled or predicted. Periodic monitoring of sediments therefore remains necessary to follow the progress of Lake Orta recovery after the liming operations carried out at the end of the 1980s. Considering the sedimentation rates in Lake Orta, the use of sediment cores with appropriate dating should be preferred to grab samples for following the future evolution of $\mathrm{Cu}$ contamination.

\section{ACKNOWLEDGMENTS}

We thank Laura Puppieni (CNR-ISE) for her help with literature research, Ivan Grof (CNR-IRSA and University of Insubria) for help with $\mathrm{Cu}$ analyses and Piero Guilizzoni and Andrea Lami for their assistance in core sampling and preparation. Credit also to two anonymous reviewers whose remarks helped to greatly improve the original submission.

\section{REFERENCES}

Appleby PG, Nolan PJ, Gifford DW, Godfrey MJ, Oldfield F, Anderson NJ, Battarbee RW, 1986. ${ }^{210} \mathrm{~Pb}$ dating by low background gamma counting, p. 21-27. In: H. Löffler (ed.), Paleolimnology IV. Developments in hydrobiology. Springer, Dordrecht.

Aziz HA, Adlan MN, Ariffin KS, 2008. Heavy metals (Cd, Pb, $\mathrm{Zn}, \mathrm{Ni}, \mathrm{Cu}$ and $\mathrm{Cr}(\mathrm{III})$ ) removal from water in Malaysia: post treatment by high quality limestone. Bioresource Technol. 99:1578-1583.

Baudo R, Amantini L, Bo F, Cenci R, Hannaert P, Lattanzio A, Marengo G, Muntau H, 1989. Spatial distribution patterns of metals in the surface sediments of Lake Orta (Italy). Sci. Tot. Environ. 87/88:117-128.

Baudo R, Beltrami M, 2001. Chemical composition of Lake Orta sediments. J. Limnol. 60:213-236. 
Baudo R, Occhipinti A, Nocentini AM, Sabolla M, 2001. Benthos of Lake Orta in the year 1996. J. Limnol. 60:241-248.

Beltrami M, Rossi D, Baudo R, 1999. Phytotoxicity assessment of Lake Orta sediments. Aquat. Ecosyst. Health 2:391-401.

Besser JM, Brumbaugh WG, Ingersoll CG, 2015. Characterizing toxicity of metal-contaminated sediments from mining areas. Appl. Geochem. 57:73-84.

Bonacina C, 2001. Lake Orta: the undermining of an ecosystem. J. Limnol. 60:53-59.

Bonacina C, Baudo R, 2001. Lake Orta: a case study. Part 1. J. Limnol. 60:1-166.

Burton Jr. AG, Baudo R, Beltrami M, Rowland C, 2001. Assessing sediment contamination using six toxicity assays. J. Limnol. 60:263-267.

Cairns MA, Nebeker AV, Gakstatter JH, Griffis WL, 1984. Toxicity of copper-spiked sediments to freshwater invertebrates. Environ. Toxicol. Chem. 3:435-445.

Calderoni A, de Bernardi R, Mosello R, 1993. Lago d'Orta ecosystem recovery by liming. In: S.E. Jørgensen (ed.), Management of lake acidification. International Lake Environment Committee. Guidelines of lake management 5:105-144.

Campana O, Blasco J, Simpson SL, 2013. Demonstrating the appropriateness of developing sediment quality guidelines based on sediment geochemical properties. Environ. Sci. Technol. 47:7483-7489.

Camusso M, Tartari G, Cappelletti E, 1989. Seasonal trends of copper sedimentation in lake Orta (Italy). Sci. Tot. Environ. 87/88:59-75.

Casati F, 2013. [I metalli in tracce nelle acque del Lago d'Orta: fase disciolta e particellata]. [Master Thesis in Italian]. Insubria University.

Cattaneo A, 1992. The anthropogenically stressed periphyton of Lake Orta, Italy. Hydrobiologia 234:111-121.

Chiaudani G, 1969. [Contenuti normali ed accumuli di rame in Phragmites communis L. come risposta a quelli nei sedimenti di sei laghi italiani].[Article in Italian]. Mem. Ist. Ital. Idrobiol. 25:81-95.

CIPAIS, 2009. [Indagini su DDT e sostanze pericolose nell'ecosistema del Lago Maggiore. Programma 2008-2012].[Report in Italian].Commissione Internazionale per la protezione delle acque italo-svizzere: $89 \mathrm{pp}$.

Corbella C, Tonolli V, Tonolli L, 1958. [I sedimenti del Lago d'Orta testimoni di una disastrosa polluzione cuproammoniacale].[Article in Italian]. Mem. Ist. Ital. Idrobiol. 10:9-50.

Dean WE Jr, 1974. Determination of carbonate and organic matter in calcareous sediments and sedimentary rocks by loss on ignition: comparison with other methods. J. Sed. Petrol. 44:242-248.

Ferrari BJD, Vignati DAL, Dominik J, 2014. Bioaccumulation kinetics and effects of sediment-bound contaminants on chironomids in deep waters: new insights using a low-disturbance in situ system. Environ. Technol. 35:456-469.

Fischer BB, Pomati F, Eggen RIL, 2013. The toxicity of chemical pollutants in dynamic natural systems: The challenge of integrating environmental factors and biological complexity. Sci. Tot. Environ. 449:253-259.

Gardham S, Chariton A, Hose G, 2015. Direct and indirect effects of copper-contaminated sediments on the functions of model freshwater ecosystems. Ecotoxicology 24:61-70.

Guilizzoni P, Lami A, Marchetto A, Appleby PG, Alvisi F, 2001.
Fourteen years of palaeolimnological research of a past industrial polluted lake (L. Orta, Northern Italy): an overview. J. Limnol. 60:249-262.

Guilizzoni P, Levine SN, Manca M, Marchetto A, Lami A, Ambrosetti W, Brauer A, Gerli S, Carrara EA, Rolla A, Guzzella L, Vignati DAL, 2012. Ecological effects of multiple stressors on a deep lake (Lago Maggiore, Italy) integrating neo and palaeolimnological approaches. J. Limnol. 71:1-22.

Guzzella L, Bartone C, Ross P, Tartari G, Muntau H, 1996. Toxicity identification evaluation of Lake Orta (Northern Italy) sediments using the microtox system. Ecotox. Environ. Safe. 35:231-235.

Hong S, Candelone JP, Patterson CC, Boutron CF, 1996. History of ancient copper smelting pollution during Roman and Medieval times recorded in Greenland ice. Science 272:246-249.

Lami A, Marchetto A, Lo Bianco R, Appleby PG, Guilizzoni P, 2000. The last ca 2000 years palaeolimnology of Lake Candia (N. Italy): inorganic geochemistry, fossil pigments and temperature time-series analyses. J. Limnol. 59:31-46.

Manca M, Comoli P, 1995. Temporal variations of fossil Cladocera in the sediments of Lake Orta (N. Italy) over the last 400 years. J. Palolimnol. 14:113-122.

Marchetto A, Bettinetti R, 1995. Reconstruction of the phosphorus history of two deep, subalpine Italian lakes from sedimentary diatoms, compared with long-term chemical measurements. Mem. Ist. Ital. Idrobiol. 53:27-38.

Marchetto A, Lami A, Musazzi S, Massaferro J, Langone L, Guilizzoni P, 2004. Lake Maggiore (N. Italy) trophic history: fossil diatoms, plant pigments, and chironomids, and comparison with long-term limnological data. Quat. Internat. 113:97-110.

Méndez-Fernández L, Martínez-Madrid M, Rodriguez P, 2013. Toxicity and critical body residues of $\mathrm{Cd}, \mathrm{Cu}$ and $\mathrm{Cr}$ in the aquatic oligochaete Tubifex tubifex (Müller) based on lethal and sublethal effects. Ecotoxicology 22:1445-1460.

Nocentini AM, Boggero A, De Margaritis G, Gianatti M, 2001. First phase of macroinvertebrate repopulation of Lake Orta (Buccione Basin) after liming. J. Limnol. 60:110-126.

Pasteris A, Vecchi M, Reynoldson TB, Bonomi G, 2003. Toxicity of copper-spiked sediments to Tubifex tubifex (Oligochaeta, Tubificidae): a comparison of the 28-day reproductive bioassay with a 6-month cohort experiment. Aquat. Tox. 65:253-265.

Piscia R, Colombini M, Ponti B, Bettinetti R, Monticelli D, Rossi V, Manca M, 2015. Lifetime Response of Contemporary Versus Resurrected Daphnia galeata Sars (Crustacea, Cladocera) to $\mathrm{Cu}(\mathrm{II})$ Chronic Exposure. B. Environ. Contam. Tox. 94:46-51.

Piscia R, Guilizzoni P, Fontaneto D, Vignati DAL, Appleby PG, Manca M, 2012. Dynamics of rotifer and cladoceran resting stages during copper pollution and recovery in a subalpine lake. Ann. Limnol.-Int. J. Lim. 48:151-160.

Piscia R, Tabozzi S, Bettinetti R, Nevalainen L, Manca M, 2016. Unexpected increases in rotifer resting abundances during the period of contamination of Lake Orta. J. Limnol. 75(s2):76-85.

Ponti B, Piscia R, Bettinetti R, Manca M, 2010. Long-term adaptation of Daphnia to toxic environment in Lake Orta: the effects of short-term exposure to copper and acidification. J. Limnol. 69:217-224. 
Potapova M, Hamilton PB, 2007. Morphological and ecological variation within the Achnanthidium minutissimum (bacillariophyceae) species complex. J. Phycol. 43:561-575.

Provini A, Premazzi G, Gaggino GF, 1987. [Valutazione del rischio potenziale da metalli pesanti nei laghi mediante l'analisi dei sedimenti].[Article in Italian]. Ing. Amb. 16:68-76.

Renberg I, 1990. A procedure for preparing large sets of diatom slides from sediment cores. J. Paleolimnol. 4:87-90.

Roman YE, De Schamphelaere KAC, Nguyen LTH, Janssen CR, 2007. Chronic toxicity of copper to five benthic invertebrates in laboratory-formulated sediment: sensitivity comparison and preliminary risk assessment. Sci. Tot. Environ. 387:128-140.

Rossi D, Beltrami M, 1998. Sediment ecological risk assessment: in situ and laboratory toxicity testing of lake Orta sediments. Chemosphere 37:2885-2894.

Ruggiu D, Lugliè A, Cattaneo A, Panzani P, 1998. Paleoecological evidence for diatom response to metal pollution in Lake Orta (N. Italy). J Paleolimnol 20:333-345

Ruttner F, 1959. [Einige Beobachtungen über das Phytoplankton norditalienischer Seen].[Article in German]. Mem. Ist. Ital. Idrobiol. 11:73-111.

Simpson SL, 2005. Exposure-effect model for calculating copper effect concentrations in sediments with varying copper binding properties: a synthesis. Environ. Sci. Technol. 39:7089-7096.

Tonolli L, 1961. [La polluzione cuprica del Lago d'Orta. Comportamento di alcune popolazioni di Diatomee].[Article in Italian]. Verh. Intern. Ver. Limnol. 14:900-904.

van Dam H, Mertens A, 1990. A comparison of recent epilithic diatom assemblages from the industrially acidified and copper polluted Lake Orta (northern Italy) with old literature data. Diatom Res. 5:1-13.

van Dam H, Mertens A, Sinkeldama J, 1994. Coded checklist and ecological indicator values of freshwater diatoms from The Netherlands. Aquat. Ecol. 28:117-133.

Vecchi M, Reynoldson TB, Pasteris A, Bonomi G, 1999. Toxicity of copper-spiked sediments to Tubifex tubifex (oligochaeta, tubificidae): comparison of the 28-day reproductive bioassay with an early-life-stage bioassay. Environ. Toxicol. Chem. 18:1173-1179.

Vignati DAL, Guilizzoni P, 2011. [Metalli nel Lago Maggiore: livelli naturali e antropici].[Article in Italian]. Acqua Aria $1: 22-27$.

Vollenweider RA, 1963. [Studi sulla situazione attuale del regime chimico e biologico del Lago d'Orta].[Article in Italian]. Mem. Ist. Ital. Idrobiol. 16:21-125. 